\title{
High protein and iron-folate crackers supplementation on the iron status of pregnant women
}

\author{
Faisal Anwar*, Eddy Setyo Mudjajanto*, Drajat Martianto*, Hakimi ${ }^{\dagger}$
}

\begin{abstract}
Abstrak
Penelitian-penelitian terdahulu telah mengajukan beberapa faktor yang dapat menyebabkan mengapa suplementasi besi pada wanita hamil masih belum memuaskan hasilnya. Faktor-faktor tersebut adalah distribusi yang tidak memadai, hasil jangkauan dan ketaatan berobat yang rendah, dan juga penyerapan usus yang rendah. Penelitian ini bertujuan untuk mengukur status besi wanita hamil setelah konsumsi biskuit yang mengandung bubuk ikan dan preparat besi-folat. Penelitian ini dilakukan di Purworejo, Jawa Tengah, dari bulan Pebruari sampai Oktober 2002. Tujuh-puluh wanita hamil dalam trimester kedua-ketiga dengan umur kehamilan antara 23 bulan ikut dalam penelitian yang menggunakan randomized controlled trial (RCT). Sepuluh wanita mengundurkan diri dan sisanya dibagi dalam dua kelompok yang terdiri dari 28 wanita yang diberikan biskuit yang diperkaya dengan protein - zat besi (kelompok PIEC) dan 32 wanita diberikan biskuit yang diperkaya dengan zat besi (kelompok IEC). Pemberian biskuit dilakukan selama 12 minggu. Dari hasil penelitian didapatkan peningkatan kadar hemoglobin $(\mathrm{Hb})$ dan reseptor transferin serum (sTfR) pada kedua kelompok. Selain itu terdapat penurunan kadar serum feritin (SF) di kedua kelompok. Namun demikian, pada akhir penelitian, peningkatan kadar Hb dan sTfR kedua kelompok ini berbeda bermakna, sedangkan penurunan SF tidak berbeda bermakna. Protein hewani berupa bubuk ikan cendrung meningkatkan absorpsi zat besi non-heme sehingga dapat meningkatkan kadar Hb dan sTfR pada wanita hamil. (Med J Indones 2003; 12: 243-6)
\end{abstract}

\begin{abstract}
Previous studies have revealed that several factors influenced the relatively low success of iron supplementation for pregnant women. The factors included poor distribution, low coverage and compliance, as well as low absorption. The aim of this study is to measure the iron status of pregnant women after consuming crackers containing fish powder and iron-folate. This study was carried out in the Purworejo district (Central Java) from February through October 2002. Using a randomized controlled trial (RCT) design, 70 pregnant women in their second-third month of pregnancy were recruited, and divided into two groups. Ten women dropped out during the study. The first group consisted of 28 women were given protein - iron enriched crackers (PIEC group), while the second group of 32 women were given iron-enriched crackers (IEC group) for a total of 12 weeks. The results showed that the hemoglobin $(\mathrm{Hb})$ levels and serum transferrin receptors (sTfR) of both groups were increased. Serum ferritins (SF) of both groups were decreased. At the end of the study, the increase in $\mathrm{Hb}$ and sTfR levels between the two groups were significantly different, while the decrease in $S F$ was not significantly different. Animal protein from fish powder tended to improve absorption of non-heme iron among pregnant women, resulting in improved Hb and sTfR levels. (Med J Indones 2003; 12: 243-6)
\end{abstract}

Keywords: pregnant women, anemia, iron deficiency, high protein crackers

Iron supplementation program for pregnant women in Indonesia was started in 1974 through the Family Nutrition Improvement Program. In this program, every pregnant woman was given one iron tablet containing $60 \mathrm{mg}$ of elemental iron and $250 \mu \mathrm{g}$ folic

\footnotetext{
* Department of Community Nutrition and Family Resources, Faculty of Agriculture, Bogor Agriculture University, Bogor, Indonesia

${ }^{t}$ Department of Obstetrics and Gynecology, Medical Faculty, University of Gajah Mada, Jogyakarta, Indonesia
}

acid for 90 days. From a survey, it was found that $60 \%$ of the pregnant women had taken 90 tablets of iron-sulfate during pregnancy. ${ }^{1}$ Although the ironfolate supplement action program has been underway for a long time, it is still not effective in reducing the prevalence of anemia among pregnant women. There was a discrepancy in the effect of iron-folate tablet supplementation in the clinical trials and in large scale programs in the community. ${ }^{2,3}$

Several factors may influence the low level of success in iron-folate supplementation programs for pregnant women. Among these were poor distribution system 
with inadequate coverage; low compliance and numerous complaints of side-effects caused by consuming iron-tablets; poor nutritional knowledge, poor awareness of the health agents and few contacts with pregnant women, and low intake of animal proteins. ${ }^{4}$ Several studies have showed that animal protein supplementation such as meat, poultry, and fish increase the bioavailability and absorption of non-heme iron in food up to 2-4 times. ${ }^{5,6}$ Therefore an idea was formed to increase the absorption of nonheme iron from iron-folate supplement by consuming animal protein. Various means of administering the supplements were explored. Among them were through crackers containing fish powder. Crackers are widely accepted, easy to make, non perishable, and easy to store. Fish was also more digestible compared to meat.

The aim of this study was to measure the effect of food powder based iron fortified crackers in improving the iron status of pregnant women.

\section{METHODS}

\section{Design and subject}

This study was a randomized controlled trial (RCT) held in Purworejo district (Central Java) from February through October 2002. Women in their second and third month of pregnancy were recruited through a community listing in the area. The inclusion criteria include women between 25-35 years of age, upper mid-arm circumference (MUAC) $13.5 \mathrm{~cm}$ or more, $\mathrm{Hb} 12.0 \mathrm{~g} / \mathrm{dl}$ or lower, and not allergic to fish or fish products. The subjects were divided into two groups systematically. The first group was given protein - iron enriched crackers (PIEC group), and the second group iron - enriched crackers (IEC group).

\section{Preparation and consumption of crackers}

Two similar packs of 12 crackers for were prepared by the Nutrition Laboratory of the Agriculture Institute of Bogor (IPB). The crackers for the PIEC group was fish powder based, while the crackers for the IEC group were not of fish powder. Table 1 shows the content of the cracker packs. One pack of crackers consisted of 12 crackers for one day. Six crackers for morning $(10.00-11.00)$ consumption, and the other 6 crackers for afternoon $(15.00-16.00)$ consumption. The intervention was conducted for a total of 12 weeks.
Table 1. Composition of cracker packs

\begin{tabular}{lcc}
\hline Composition & $\begin{array}{c}\text { Enriched crackers } \\
(\text { PIEC) }\end{array}$ & $\begin{array}{c}\text { Non-enriched } \\
\text { crackers } \\
\text { (IEC) }\end{array}$ \\
\hline Number of crackers & 12 & 12 \\
Enrichment & & \\
$\quad$ Ingredients & Fish powder & None \\
Weight $(\mathrm{g})$ & 85 & 85 \\
Energy $(\mathrm{KCal})$ & 465 & 451 \\
Protein $(\mathrm{g})$ & 13.6 & 7.3 \\
Iron $(\mu \mathrm{g})$ & 60 & 60 \\
Folic acid $(\mu \mathrm{g})$ & 500 & 500 \\
\hline
\end{tabular}

\section{Data collection and analysis}

Food consumption was obtained by using "24-hour recall" through interview with open questions once a week. Nutritional status was obtained by measuring mid upper arm circumference (MUAC) using a tape measuring device to the nearest $0.1 \mathrm{~cm} .{ }^{6,7}$

Blood was tapped at the beginning and at the end of the study. One millimeter cubic (cc) blood was used for measuring hemoglobin using Single Radial Immuno-Diffusion Photometric Method (Sigma). Nine cc were stored at room temperature and centrifuged for analysis of serum ferritin (SF) using Radio Immuno Assay with Gamma Counter device (Shimadzu) and serum tranferrin receptor (sTfR) using ELISA with Auto Analyze Device (Sigma). The data were analyzed using the student's-t Test with STATA 7.0.

\section{RESULTS}

A number of 70 women participated in the study. During the study, 10 women dropped out due to various reasons. Out of 70 women, 28 were in the first group and 32 were in the second group.

\section{Iron status at pre-test}

Table 2 shows the iron status of the IEC group and the PIEC group, from the hemoglobin, serum ferritin, and serum transferring receptor levels at pre-test, post-test, and the differences between the values. 
Table 2. Delta Hb, SF, sTfR pre-test and post-test

\begin{tabular}{lccccccc}
\hline & \multicolumn{2}{c}{ IEC Group } & Difference & \multicolumn{2}{c}{ PIEC Group } & Difference & P value \\
& Pre-test & Post-test & & Pre-test & Post-test & & \\
\hline Hb level $(\mathrm{g} / \mathrm{dl})$ & $10.31 \pm 0.7$ & $10.62 \pm 0.8$ & 0.32 & $10.30 \pm 0.8$ & $11.11 \pm 0.9$ & 0.81 & 0.07 \\
SF level $(\mu \mathrm{g} / \mathrm{dl})$ & $17.78 \pm 11$ & $13.45+5.9$ & -4.32 & $23.18 \pm 13$ & $14.73 \pm 8.2$ & -8.44 & 0.29 \\
$\operatorname{sTfR}(\mathrm{mg} / \mathrm{dl})^{\mathrm{c}}$ & $6.83 \pm 3.0$ & $9.26 \pm 2.5$ & 2.42 & $7.29 \pm 3.3$ & $7.72 \pm 1.67$ & 0.43 & 0.04 \\
\hline
\end{tabular}

$\begin{array}{ll}\text { IEC Group } & : \text { iron (only) enriched cracker group } \\ \text { PIEC Group } & : \text { protein-iron enriched cracker group } \\ \text { Hb } & : \text { hemoglobin } \\ \text { SF } & : \text { serum ferritin } \\ \text { STfR } & : \text { serum transferring receptor }\end{array}$

Hemoglobin and serum transferring receptor levels among women in the IEC and the PIEC groups at pretest were not significantly different. Although the average value for serum ferritin of the PIEC group was relatively higher than in the IEC group, they were not significantly different. This means that the randomization of the subjects at the beginning of the study was achieved.

\section{Iron status at post-test and the difference compared to the status at pre-test}

Table 2 also shows that the hemoglobin level of women in the PIEC group was more elevated than those of women in the IEC group. The average $\mathrm{Hb}$ level of the IEC group in the post-test was $10.62 \mathrm{~g} / \mathrm{dl}$ with an average increase of 0.32 , while in the PIEC group it was $11.12 \mathrm{~g} / \mathrm{dl}$ with an average increase of 0.85 . The difference was significant. The average value of serum ferritin in the IEC group was decreased to $13.45 \mu \mathrm{g} / \mathrm{l}$ with an average of 4.32 points. In the PIEC group it was $14.73 \mu \mathrm{g} / \mathrm{l}$ with an average of 8.44 points. The difference was also significant. The average sTfR content of the IEC group was increased to $9.26 \mathrm{mg} / \mathrm{l}$ with an average increase of 2.42 points. In the PIEC group it was 7.72 $\mathrm{mg} / \mathrm{l}$ with an average increase of 0.43 point. The difference was also significant.

\section{DISCUSSION}

The increased hemoglobin level in the PIEC group was significantly higher than in the control (IEC group). Although the increase was not high, the findings may support the role of meat and fish (MPF) proteins in enhancing absorption and metabolism of iron, especially non-heme iron. The findings were also consistent with the findings of previous studies that showed adding MPF significantly increased dietary absorption of iron. ${ }^{8}$ The finding of this study was also consistent with another study that showed the availability of protein influenced the whole process of iron metabolism, starting from absorption, transportation, and the process of anabolism and catabolism. In each case, animal proteins played a significant role. ${ }^{9}$

The study did not show a improved increased in serum ferritin through addition of animal protein (fish powder) in the PIEC group. This finding could be explained by the role of ferritin, which is mainly in iron storage and does not directly reflect the adequacy of iron in the blood or in other heme or non-heme cells. ${ }^{10}$ Serum ferritin is also affected by inflammation. Therefore, the serum ferritin level is not specific for measuring iron stores when inflammation is present. Pregnancy itself is another confounding variable for serum ferritin. Therefore, serum ferritin is not a reliable indicator for measuring iron levels and status in pregnant women. ${ }^{11}$

In this study, the increase in sTfR of women in the PIEC group were significantly lower after intervention when compared to the IEC group. Transferrin has a role in the transportation of iron. The serum transferrin receptor is a key iron-related protein which regulates the influx of transferrin iron in all cells. A soluble form of the transferrin receptor has been identified in human serum which reflects the total 
body mass of cellular transferrin receptor. The increment of sTfR concentration in patients suffering from iron deficiency indicates the existence of hyperplasia precursor erythroid process. ${ }^{6}$

In this study, sTfR in both groups was increased instead of decreased. This might be related to some condition. All the women, including those in the PIEC group were anemic, and were still anemic until the end of the study. Assuming that the anemia was due to iron deficiency might somehow explain why sTfR was still increasing. In addition, the duration of the intervention of only 12 week might also be too short to expect a decrease in sTfR among women in the PIEC group. The much lower increase of sTfR in the PIEC group showed that of iron deficiency was better controlled by adding animal protein in the supplement.

The use of sTfR rather than ferritin in evaluating the iron status was more suitable in certain conditions such as pregnancy, where iron depletion is frequently found.

In conclusion, enriching iron-folate supplement for anemic pregnant women by adding animal protein from fish powder can improve anemia, especially in anemia caused by iron deficiency, and was marked by the higher increase in hemoglobin level and lower serum transferrin receptor 9sTfR.

Food-based intervention, such as by enriching with animal protein, for controlling anemia in pregnant women should be considered. Various protein sources should be reviewed, and fish powder should be strongly considered. Various vehicles for the purpose should also be considered.

\section{Acknowledgements}

The authors would like to thank Drs. Hadi Riyadi, Satoto, and Jose Cardona for their critical review of the early drafts. We would also like to acknowledge the late Sumali Miran Atmojo, the previous team leader of this study who passed away during the implementation of the study. We are grateful to the Director General of Community Health of the Ministry of Health Republic of Indonesia, and the Social Safety Net in Health for providing financial support for this study.

\section{REFERENCES}

1. Kodyat BA, Kosen S, dePee S. Iron deficiency in Indonessia: Current situation and intervention. Nutr Researh 1998;18:1953-63.

2. Yip R. Iron supplementation during pregnancy: Is it effective? Am J Clin Nutr 1996;63:853-5.

3. Beard JL. Effectiveness and strategies of iron supplementation during pregnancy. J Am Clin Nutr 2000; 71 Suppl 1:1288-94.

4. Stephens C. Reducing maternal anemia through community participation: Bangalore, India. MotherCare/John Snow Inc.: USAID; 1999.

5. Australian Iron Status (AIS) Advisory Panel. Iron status and pregnancy: Diagnostic issues (http://www.ironpanel.org.au); 2000.

6. Cook JD, Monsen ER. Food iron absorption in human subjects. III. Comparasion of the effect of animal proteins on non-heme iron absorption. Am J Clin Nutr 1992; 29:859-67.

7. Rasmussen BE, Hallberg L. Effect of animal protein on the absorption of food iron in man. Nutr Metab 1979;23:192-202.

8. Cook JD, Dassenko SA, Lynch SR. Assessment of the role of non heme-iron availability in iron balance. Am J Clin Nutr 1976;54:717-22.

9. Brabin BJ. An analysis of anemia and pregnancy-related maternal mortality. Paper presented in Conference of Iron Deficiency Anemia: Reexamining the nature and magnitude of public health problems. Maryland: Belmont Conference Center; 21 - 24 May 2000.

10. Davidson L. Iron bio availability from weaning food: The effect of phytic acid in micronutrient interaction. Impact on child health and nutrition. Washington: ILSI; 1998.

11. Gibson RS. Nutrition assessment: A Laboratory manual. New York: Oxford University Press; 1993. 